\title{
A Linguagem Mariológica dos Padres Capadócios
}

\section{Mariological language of the Cappadocian Fathers}

\author{
Maria Freire da Silva
}

\section{Resumo}

A presente reflexão pretende verificar a linguagem mariológica na segunda metade do século IV, na Capadócia. Há um grande florescimento no pensamento teológico através de Basílio de Cesaréia, Gregório Nazianzeno e Gregório de Nissa. Primeiramente seu interesse versa sobre a cristologia e teologia trinitária. Defensores da fé nicena contra os arianos, constituem o ponto de referência do pensar teológico Patrístico Oriental. A reflexão sobre Maria nesse período articula-se sempre com a defesa da divindade, ou com humanidade de Jesus Cristo. Daí a importância da questão sobre a Virgem Maria nos padres capadócios.

Palavras-chave: Linguagem Mariológica. Maria Virgem. Mãe de Deus.

\begin{abstract}
This reflection intends to examine mariological language in the second half of the fourth century in Cappadocia. There is a great flourishing in theological thought through Basil of Caesarea, Gregory of Nazianzus and Gregory of Nyssa. Their interest primarily deals with Christology and Trinitarian theology. Defenders of the Nicene faith against the Arians, they constitute the reference point for Eastern Patristic theological thought. Reflection on Mary in this period is always articulated with a defense of the divinity or of the humanity of Jesus Christ. Therefore,
\end{abstract}


the importance of the question of the Virgin Mary in the thought of the Cappadocian fathers.

Keywords: Mariological language. Virgin Mary, Mother of God.

\section{Introdução}

Os dois primeiros séculos do cristianismo foram importantes para a história da Mariologia. Neste tempo, aparecem os grandes escritores que falam de Maria, ao lado dos escritos apócrifos, produzidos para satisfazer a necessidade de falar sobre a vida de Cristo e de Maria. $\mathrm{O}$ chamado protoevangelho de Tiago, datado no final do II século, fala do nascimento de Maria. O mesmo influenciou muitas lendas sucessivas sobre a Mãe de Jesus, bem como a arte figurativa. ${ }^{1}$

Os testemunhos sobre Maria, no Segundo Testamento e nos Apócrifos, como também a preeminência da cristologia nas disputas teológicas dos primeiros séculos, tornaram também a Mariologia um tema da Patrística. Embora, a princípio, os Padres não dispusessem ainda dos termos teológicos adequados para expressar o mistério cristológico, a dignidade e o significado salvífico da Mãe de Deus, no entanto desde o início os testemunhos da Escritura e da Tradição apostólica foram por eles corretamente interpretados, aplainando o caminho para os sucessivos desenvolvimentos da mariologia.

A posição dos Padres da Igreja expressou-se, sobretudo, no âmbito de outros temas, a serviço seja do ensinamento da fé (Catequese) seja de sua defesa (Apologia) contra as várias heresias, principalmente contra o judaísmo e a gnose. Nem o Novo Testamento nem os escritos dos Padres oferecem uma mariologia sistemática, mas apenas peças de mosaico sobre pontos doutrinais individuais e sobre a figura ética de Maria, que o evangelista Lucas havia delineado.

\footnotetext{
${ }^{1}$ O Proto-Evangelho de São Tiago é conhecido como a Natividade de Maria e se tornou o mais célebre dos livros Apócrifos, o primeiro a ter Maria como tema. De forma popular, com escassa documentação histórica quer defender a virgindade de Maria antes, durante e depois do Parto, e delinear uma imagem de Maria que compreendia o Primeiro Testamento e prefigurava o Segundo Testamento. Maria aparece como dom da graça e Templo, isto é, Arca do Senhor. Esse livro influenciou profundamente toda a Tradição cristã.
} 


\section{Contextualização: os elementos mariológicos da primeira pregação da Igreja}

No primeiro século o centro do anúncio cristão é constituído pela fé em Cristo Filho de Deus. Na época subapostólica, ao credo cristológico do Novo Testamento se acrescentará a menção do nascimento de Jesus Cristo de Maria Virgem. Esta expressão permanecerá presente em todas as profissões de fé. ${ }^{2}$

A maternidade e a virgindade são afirmações bíblicas presentes nos evangelhos de Lucas e Mateus, sobre as quais se constroem a primeira doutrina mariológica. Os autores cristãos enfrentam dois grupos: o primeiro é o cristianismo judeu heterodoxo, entre os quais estavam os "ebionitas"; ${ }^{3} \mathrm{o}$ segundo formado pelos adeptos do gnosticismo. ${ }^{4} \mathrm{O}$ empenho dos autores cristãos ortodoxos ${ }^{5}$ em relação à mariologia consistirá em salvaguardar o que haviam recebido do querigma primitivo.

O contexto histórico-doutrinal, no qual se desenvolvem as pesquisas e as propostas mariológicas dos padres antigos, é a encarnação do Verbo. Por sua íntima natureza, a Virgem Maria, sua figura e sua missão se inserem no coração do plano divino, atuante em Cristo e na Igreja.

Entre os "Padres Apostólicos" Inácio é o único a falar de Maria e da sua maternidade virginal. É um expoente da Escola de Antioquia da Síria e a primeira testemunha da inserção da doutrina mariológica no patrimônio dogmático da Igreja. Das cartas autênticas deste bispo-mártir emergem elementos concernentes à Virgem Maria que são patrimônio da fé da Igreja. Em contraposição aos docetas, Inácio de Antioquia apresenta sua compreensão mariológica estritamente interligada ao mistério da encarnação.

$\mathrm{Na}$ carta aos Efésios afirma que três mistérios permanecem ocultos ao príncipe deste mundo: a) a virgindade de Maria; b) seu parto; c) a morte do

\footnotetext{
${ }^{2}$ DAMIGELLA, G., Il mistero di Maria, teologia, storia, devozione, p. 107.

${ }^{3}$ KOESTER, H., Introdução ao Novo Testamento, p. 220. "Ebionitas" eram judeus cristãos de lingual grega. Foi considerado um grupo "herege" porque não aceitavam o nascimento virginal, por isso, omitiam as narrativas do nascimento de Jesus no seu evangelho. Segundo PERETTO, E., Mariologia Patrística, p. 703, outra corrente ebionita aceita que o Senhor tenha nascido da Virgem e do Espírito Santo, mas nega a pre-existência como Verbo de Deus e Sabedoria do Pai. ${ }^{4}$ Gnosticismo deriva de "gnose", que em grego significa conhecimento. Tal conhecimento se alcança por meio de uma revelação divina vinculada à faísca de Deus adormecida nas pessoas. É um pensamento fortemente dualista. A matéria é entendida como prisão das centelhas divinas. ${ }^{5}$ Aqui o termo "ortodoxo" significa aquilo que se conforma com a doutrina religiosa tida como verdadeira.
} 
Senhor. São três mistérios realizados no silêncio de Deus. A Maternidade autêntica e criação virginal constituem um entrelaçamento no pensamento de Inácio de Antioquia. ${ }^{6}$ No confronto dialético do humano e do divino em Jesus Cristo, aflora a sua fé na divindade e na humanidade de Jesus Cristo, nascido de Maria e de Deus. Ele preparou as posteriores declarações do Concílio de Calcedônia, dando à virgindade de Maria, à sua concepção e à morte do Senhor o nome de "três grandiosos mistérios". Com esses três elementos de notável significado teológico, demonstra o sábio envolvimento de Maria no desígnio da salvação.

A preocupação inaciana é por uma cristologia histórica em antítese com as especulações dos setores gnósticos. Defendeu contra o Docetismo ${ }^{7}$ a realidade da encarnação de Cristo como pressuposto para uma justa compreensão da maternidade divina de Maria. Nessa ótica, Inácio de Antioquia insiste sobre o nascimento biológico do Senhor de Maria designada com o título de virgem: "Pois nosso Deus, Jesus, o Cristo, tomou carne no seio de Maria segundo o plano de Deus, sendo de um lado descendente de Davi, provindo por outro do Espírito Santo". 8

A maternidade divina é, com efeito, base indiscutível e garantia da encarnação do Filho de Deus. A salvação que a Igreja professa não é uma pura revelação desencarnada de mistérios celestes como queriam os gnósticos heréticos; está sim composta de feitos e ações verdadeiras e humanas de Cristo que é Deus encarnado em Maria.

Inácio ensinava às comunidades que deviam fechar os ouvidos se alguém falasse ou ensinasse algo fora de Jesus Cristo que descende da linhagem de Davi, e é Filho de Maria, que nasceu verdadeiramente comeu e bebeu e foi verdadeiramente perseguido sob Pôncio Pilatos, foi verdadeiramente crucificado e morreu, ressuscitou verdadeiramente dentre os mortos. A realidade histórica de Cristo é, pois, a única salvação. ${ }^{9}$

\footnotetext{
${ }^{6}$ INÁCIO DE ANTIOQUIA, Policarpo Martirio di Policarpo, p. 50.

${ }^{7}$ PERETTO, E., Mariologia Patrística, p. 704-705. A nota distintiva do Docetismo é a afirmação que Cristo não tinha um corpo real e espiritual ou psíquico, mas um corpo fantástico. Era um fantasma, não uma realidade. Esta posição foi tratada e condenada no Concílio de Nicéia. Também Inácio de Antioquia e Tertuliano manifestam, por escrito, suas posições antidocetistas. No início do II século, da Escola de Antioquia da Síria vem a posição teológica clara sustentando o nascimento real e corporal de Jesus de uma mulher. Diz Inácio: Jesus não é um homemsombra, um fantasma nem antes, nem depois da ressurreição.
}

${ }^{8}$ INÁCIO DE ANTIOQUIA, Aos Efésios, XVIII,2.

${ }^{9}$ TONIOLO, E., Padres de La Iglesia, p. 1516-1553. 


\section{Os Padres capadócios}

Os capadócios, Basílio de Cesaréia (379), Gregório Nazianzeno (390) e Gregório de Nissa (394) compõem o grupo original, de inspiração alexandrina, que influenciou profundamente a tradição bizantina posterior em todos os setores: dogmático, moral ascético, litúrgico e canônico. Basílio deu traços iniciais à doutrina trinitária sendo seguido por Gregório Nazianzeno, seu irmão Gregório de Nissa e outros amigos. Constituem, portanto, os principais criadores da linguagem trinitária Oriental. Também em âmbito mariológico os três apresentam sua linha em conexão com Orígenes.

\subsection{Basílio de Cesaréia (379)}

No campo mariológico, Basílio bispo de Cesaréia, confirmou com o peso de sua autoridade o que já havia sido anteriormente intuição de Orígenes: a perpétua virgindade de Maria. Através de sua célebre homilia na festa da Natividade, que hoje se lê nas Igrejas do Oriente, recorre aos textos bíblicos paralelos, tenta esclarecer expressões do evangelho como: mulher, não conheceu até que deu à luz a seu primogênito. Na opinião de Basílio, o fato de Maria não conhecer alguém significa um grande serviço prestado à geração do Senhor efetuado por obra do Espírito, e que após nascimento de Jesus não teria renunciado à vida matrimonial. Para Basílio o que acontece depois era indiferente ao mistério. Diz que a perpétua virgindade não é indispensável ao Projeto salvífico de Deus. ${ }^{10}$ Porém seu maior apoio é o sensus fidelium. Para ele, Maria é a mãe de Deus (a Theotókos), aquela que deu uma carne portadora de Deus. Jesus foi concebido no seio de Maria por intervenção do Espírito Santo, a qual se tornou mãe sem a perda da virgindade. Afirma que somente Deus pode nascer de uma virgem, e essa continuar virgem. A virgindade apresenta-se como uma prova segura da santidade de Maria. Esse pensamento insere-se no contexto eclesial em que se multiplicava o número das mulheres e dos homens que consagravam sua virgindade ao Senhor na vida monástica. $\mathrm{O}$ próprio Basílio é fundador e codificador da vida monástica em semelhante contexto onde virgindade e santidade eram sinônimos.

${ }^{10}$ TONIOLO, E., Padres de La Iglesia, p. 1514-1553. 
A respeito do tema da virgindade da Mãe de Deus, Basílio recorre às convicções recebidas da Tradição não escrita. Referindo-se a Mt 1,25, onde o evangelista diz que José não conhece sexualmente sua esposa até ter por filho seu primogênito, Basílio comenta que a virgindade era um serviço necessário à encarnação e que não há testemunho suficiente de que não permanecesse virgem. Ainda baseado no sensus fidelium afirma que José assume a custódia de Maria como Protetor. Quando José se afasta de Maria, não ignora a intervenção do Espírito Santo, e teme interferir em um mistério tão grande e embaraçar a ação do Espírito. ${ }^{11}$

Em sua homilia, a Virgem desponta como modelo todo particular da alegria que é a alma da celebração litúrgica; enquanto dispõe intimamente à glorificação do Senhor. Faz entender que a alegria de Maria não é uma alegria comum, porque ela aprendeu a se alegrar com Gabriel. É uma disposição interior extraordinária, messiânica que vem do céu. Por isso, se torna modelo de vida e de fé e de atitude litúrgica para os cristãos.

\subsection{Aspectos da Linguagem Mariológica de Gregório Nazianzeno (390)}

Os padres capadócios são modelos através dos quais se pode falar da tradição mariana. $\mathrm{O}$ material que se recolhe nos escritos de Nazianzeno demonstra semelhança com o de Basílio, seja por sua questão quantitativamente reduzida, ou por seus conteúdos que são relativos aos mistérios de Cristo; mistério que impõe um dúplice debate trinitário contra os arianos e um debate sobre a encarnação contra os apolinaristas. A Virgem obviamente encontra a sua inserção no segundo tipo de debate.

Nazianzeno como todos os padres anteriores a Éfeso (431), não compôs nenhuma sistematização mariológica. Limitou-se a adentrar no tema, de forma a refletir e aprofundá-lo tendo como ponto de partida os aspectos que emergiam da cristologia e da soteriologia. Aqui o termo "ortodoxo" significa aquilo que se conforma. Os elementos marianos eram suportes integrativos ao argumento central. Quando falava aos fiéis, Nazianzeno supunha já a narrativa do evangelho comentado na homilia tradicional do culto litúrgico. Fala com precisão e incisiva evidência de linguagem. Faz uma inter-relação entre o seio da Virgem e o Deus-Homem que germinou sob o dinamismo do Espírito Santo, inabitando em um templo, um sacro

${ }^{11}$ TONIOLO, E., Padres de La Iglesia, p. 1514-1553. 
templo: a mãe foi templo do Cristo. Dá ênfase à encarnação, porém enfatizando a Virgem intacta. É um teólogo severamente concentrado, que examina a realidade. ${ }^{12}$

\subsubsection{Analogia sobre a virgindade}

Sua linguagem mariológica emerge diante da não aceitação por parte dos pagãos, que afirmam que a encarnação foi uma segunda criação, onde Cristo pôs seus comportamentos em paralelo com os nossos; provém de uma mulher em socorro de Eva: a mulher garante a humanidade, a virgem "garante" a divindade. ${ }^{13}$ Com resolução audaz e controlada que lhe é típica, Nazianzeno toma o conceito de virgindade na concretude social e jurídica do celibato lexicalmente da ausência de um jugo matrimonial, vocábulo que, em uma especial acepção, pode convir tecnicamente à Maria, enquanto relacionada com Deus. Não se trata, porém, de um impulso ocasional, pois em seguida afirma que a primeira virgem é a Trindade. Nazianzeno mantém ao mesmo tempo, um Deus distante e próximo, o faz com paixão, através da própria experiência. Há uma verdadeira pericorese na dialética humanidade e divindade de Cristo. ${ }^{14}$

Portanto, é oportuno concentrar a atenção sobre a carta 101 de Gregório Nazianzeno endereçada ao presbítero Cledônio, onde se encontra uma série de anátemas contra os hereges, nos quais Gregório condena os erros que circulavam a respeito da Mãe de Jesus:

Se alguém não acredita que a virgem Maria é Mãe de Deus (a Theotókos), seja separado da divindade. Se alguém pretende que Cristo seja somente passado através de Maria como se passa num canal, e nega que ele foi plasmado em seu seio de modo divino sem intervenção humana, e, em modo humano, ou seja, conforme a lei da concepção seja igualmente ateu. ${ }^{15}$

Gregório Nazianzeno ainda afirma radicalmente a condenação de alguém ao afirmar que primeiro é formado o homem que somente em seguida

\footnotetext{
12 TRISOGLIO, F., San Gregorio di Nazianzo: un contemporaneo vissuto sedici secoli fa, p. 288-289.

${ }^{13}$ GREGÓRIO NAZIANZENO, Tutte le orazioni, p. 335.

${ }^{14}$ TRISOGLIO, F., San Gregorio di Nazianzo, p. 289.

${ }^{15}$ GREGÓRIO NAZIANZENO, Apud: GAMBERO, L., I padri cappadoci (Basilio Magno, Gregorio Nazianzeno, Gregorio Nisseno) testimoni della tradizione mariana, p. 7.
} 
é revestido da divindade. Acusa de adocionista àqueles que argumentam a noção de dois filhos: um de Deus Pai e outro de Maria. Isso nos atesta que Gregório Nazianzeno é o primeiro padre a utilizar o termo Theotókos como verdade própria, contra Apolinário, que após utilizar o termo Theotókos negava a verdadeira maternidade divina. O termo será indicado cinquenta anos depois, como critério e garantia de uma reta cristologia pelo Concílio de Éfeso (431).

Também afirma a virgindade no parto, e o faz apresentando-a como modelo ascético a ser seguido. Afirma uma prévia purificação operada pelo Espírito Santo no ato da anunciação fazendo-a capaz de conceber o Filho de Deus. No entanto, não se pode afirmar que Nazianzeno quisesse sustentar uma preservação do pecado original, embora, em sucessivo desenvolvimento era evidente, que por amor a Cristo, Maria devia ser purificada. ${ }^{16}$ Apresenta um precioso testemunho sobre a fé popular no valor da intercessão de Maria. ${ }^{17}$

Vem o Deus imortal, reunindo duas naturezas (humana e divina) em um só ser. Uma permanece escondida e a outra se revela à humanidade. Porém um único Deus, já que o homem está unido à divindade. Segundo Gregório Nazianzeno sendo verdadeiramente Deus e homem, Cristo advém como Filho inteligível e visível. Em resposta a Apolinário afirma:

Tu não vês que como um só sujeito único possa conter duas naturezas perfeitas... A alma somente recebeu o intelecto e a razão. Não é grande coisa para ti, a mente onde Deus está presente? Se me falas de carne sem mente então me dilui. Se o Verbo tinha alma, mas, qual alma? Tu não vês que a geração é aquela de Deus na virgem, como se harmonizam em um só sujeito duas identidades em natureza contrastantes? O Espírito purificador desce sobre a virgem o verbo se plasmou no seio dela de natureza humana, devendo ser totalmente oferecida em resgate pelo homem inteiro. ${ }^{18}$

À sua compreensão sobre a prévia da purificação, adiciona os conceitos de que era o Verbo mesmo Deus, Aquele que existia antes de todos os séculos:

\footnotetext{
${ }^{16}$ A constante celebração de pureza e de ausência da mancha em Maria proclamada por Nazianzeno, intensificando a tradição eclesial, excluía a ideia de qualquer culpa. Há aqui uma sublimação da maternidade divina. A especial purificação é uma luz apontada por Cristo. A maternidade imaculada pressupõe uma maternidade virginal. A Virgem está no ápice de uma lei universal, a realiza e a consagra.

${ }^{17}$ TONIOLO, E., Testi mariani del primo millennio, p. 333.

${ }^{18}$ TONIOLO, E., Testi mariani del primo millennio, p. 306.
} 
o invisível, o incompreensível, o incorpóreo, princípio de todo princípio, luz da luz, fonte de vida e de imortalidade, modelo da beleza arquetípica, definição e Palavra do Pai. Vem em sua própria imagem e se encarna, sendo em tudo igual ao humano exceto no pecado. Fala de uma alma racional, do verbo, o que contraria Apolinário que negava tal existência. Afirma que o Filho é passível na carne impassível na divindade, circunscrito no corpo e ilimitado no espírito. O mesmo ser é terreno e celeste, visível inteligível, compreensível e incompreensível. ${ }^{19}$

A respeito da virgindade diz que Maria tornou-se mãe permanecendo virgem. Faz uma relação da metáfora do monte ardendo e não se consumindo, com a virgem dando a luz e não se corrompendo. Nazianzeno parece utilizar os apócrifos (proto-evangelho de Tiago) para descrever sobre os pais, a infância e o casamento de Maria com José.

Pensa Maria como protótipo e modelo de uma virgindade na perspectiva da maternidade de Cristo, metáfora da fecundidade sobrenatural, de modo que propõe uma imitatio Virginis. No entanto, humaniza a Virgem ao refletir da necessidade de uma atmosfera familiar, o casamento com José e recenseamento de Augusto. Numa leitura de Mateus e Lucas, questiona, como pode o Deus imortal nascer de uma virgem mortal? Pode se dizer que em Nazianzeno a Virgem aparece nas temáticas mais díspares nos horizontes imensos e nas questões pormenores à eternidade à contingência. ${ }^{20}$

O fundamento essencial da mariologia é construído a partir da interdependência das duas naturezas do Cristo. O desenvolvimento sobre a encarnação é posto em forte evidência, com essencialidade, sem retórica; uma linguagem teológica, perpassada de uma animação lírica, que infunde um palpite controlado que não atenua a lucidez da reflexão. Apresenta uma devoção convicta que nasce do pensamento e não de um sentimento exaltado que recorre adjetivos, metáforas e fantasias. Põe a Virgem em estreita conexão com Cristo sem divinizá-la. ${ }^{21}$ Nazianzeno é um homem de estilo rico, às vezes até esplendoroso", conhecedor da cultura pagã, hábil na escrita, poeta por excelência. Utiliza seu conhecimento para defender a fé contra o apolinarismo.

\footnotetext{
${ }^{19} \mathrm{O}$ termo esclarece a perspectiva trinitária relacional entre o Pai e o Filho.

${ }^{20}$ TONIOLO, E., Testi mariani del primo millennio, p. 301. Na humanidade da Virgem Deus se faz humano.

${ }^{21}$ TONIOLO, E., Testi mariani del primo millennio, p. 304.
} 
Gregório de Nissa, ${ }^{22}$ um dos pioneiros na articulação entre cristianismo e filosofia platônica, elabora sua mariologia apresentando uma figura de Maria em referência ao Filho, e, em íntima relação com sua obra redentora. ${ }^{23}$ Embora, não ofereça um tratado sobre Maria, apresenta uma mariologia rica e radicada na tradição anterior, especificamente em Irineu de Lião no que se refere ao paralelismo: Eva-Maria. ${ }^{24} \mathrm{O}$ tema sobre a maternidade virginal perpassa seus escritos, onde aparece o termo Theotókos. Em argumentação contrária a Apolinário de Laodicéia, afirma que Jesus é verdadeiro homem, porque é filho de Maria e, carne humana, não carne celestial, e que Maria é verdadeira Mãe de Deus, porque Jesus Cristo é consubstancial ao Pai e, portanto, é Deus. ${ }^{25}$

Ao retomar o AT, denomina Maria de templo de Cristo, templo do Verbo. Disso deriva a vitória sobre o dragão. Trata-se de elaborar uma visão mariológica capaz de mostrar que através da virgindade de Maria é superada a morte que reinava em Adão. Utiliza o conceito Theotókos, aplicando a distinção entre Maria e as outras mulheres. Demonstra incompatibilidade entre o termo Theotókos e o termo anthropotokos. Pode-se dizer que nessa visão, aparecem duas questões fundamentais com implicância na futura controvérsia nestoriana:

A Virgem é Mãe de Deus desde o instante da concepção de Jesus, portanto não pode ser chamada de anthropotókos. Os antioquenos partem do pressuposto aristotélico de que a uma natureza humana corresponde uma subsistência humana própria, falando de conjunção externa de inabitação do Verbo em um homem, de união moral devido a benevolência e não segundo a substância; portanto, no interior da união das duas naturezas conservam sempre suas próprias características e não é lícito seu intercâmbio entre as duas naturezas, o que não permite legitimamente

\footnotetext{
${ }^{22}$ Nissa se apresenta na literatura cristã como um dos maiores exegetas do Cântico dos Cânticos e como campeão da interpretação alegórica.

${ }^{23}$ MATEO-SECO, F. L., Mariologia, p. 374-378.

${ }^{24} \mathrm{O}$ paralelismo esboçado por Justino, e aprofundado por Irineu, constituía primeira tentativa de reflexão mariológica, origenista com a intenção de explicar o desenvolvimento e a função de Maria na história salvífica. Orígenes insere no desenvolvimento dessa reflexão Lc 1,28 (GIANOTTO, C., Maria, p. 263-266).

${ }^{25}$ MATEO-SECO, F. L., Mariologia, p. 374-378.
} 
afirmar que Maria é a Theotókos, sim a Christotókos, porque o Verbo não pode nascer de uma mulher. ${ }^{26}$

\subsubsection{Quatro passos fundamentais em sua linguagem}

Gregório de Nissa argumenta a partir de quatro passos fundamentais da Sagrada Escritura: a) a narrativa da anunciação (Lc 1, 26-38), onde Maria recebe a força do altíssimo que a faz imaculada. O Verbo edificou a sua casa; b) o episódio da sarça ardente (Ex 3,1-6); c) a Profecia de Isaías (Is 7,14), apresenta o texto de Isaías afirmando que é o anúncio já de forma profética sobre a mãe de Deus sem esposo, da carne sem pai, do parto incorrupto; d) e onde a sabedoria constrói a própria casa $(\mathrm{Pv} 9,1)$.

Há em seu pensamento a negação de um parto doloroso da Virgem em contraposição ao de Eva. Demonstra que o parto virginal se insere em âmbito mais amplo do senhorio do Cristo sobre a lei da natureza: trata-se de um senhorio coerente com sua dignidade divina, já interligada à renovação da natureza mediante o corpo ressuscitado. ${ }^{27}$

Em sua obra sobre o Cântico dos Cânticos, 13, afirma o senhorio justificado apela brancura e pelo vermelho: Carne e sangue. A afirmação de que Cristo vem através de um novo gênero de parto, objetiva preservar o seu domínio sobre a natureza e sobre os tempos. ${ }^{28}$ Analisa Isaías 7,14, com o objetivo de afirmar que o profeta preanuncia o que se realizará: o salvador haveria de superar a lei da natureza na virgindade de sua concepção e de seu nascimento. Daí que o termo parthenos usado na LXX na tradução de Is 7,14, não equivalente a "jovem", mas a "virgem" em sentido técnico. Percebe-se aqui uma beleza frasal que exprime com eloquência seu pensamento: Maria tornou-se mãe permanecendo virgem.

Há uma dialética: a maternidade divina e a maternidade virginal se conjugam a serviço da história da salvação, dando início à renovação do mundo e da lei da natureza. Maria torna-se espaço dessa realização. A partir dessa compreensão contrariando o Docetismo, a antropologia nicena vem minuciosamente repleta de uma análise entre o corpo humano como criação

\footnotetext{
${ }^{26}$ SARTOR, D., Madre de Dios, p. 1173-1199.

${ }^{27}$ É fundamental aqui, considerar que Gregório de Nissa é um escritor que contém argumentos eficazes e relevante a respeito da Apocatástase no século IV. Sua elaboração mariológica não está isenta desse percurso referente a sua concepção de homem novo e de futuro escatológico.

${ }^{28}$ GREGORIO NAZIANZENO, Omelie sul cantico dei cantici, p. 215.
} 
de Deus e a indignidade do pecado. O elemento principal de preservação da carne de Maria é a descida do Espírito Santo sobre ela. ${ }^{29}$ Gregório de Nissa traz uma contribuição, referente à virgindade no parto, fundamentando-a em Ex 3,3.

\subsubsection{Aspectos relevantes de sua linguagem mariológica}

Do ponto de vista de Gregório de Nissa, Maria se propunha a ser virgem, o que levou posteriormente, à afirmação de que ela tinha voto de castidade, como afirma Agostinho. ${ }^{30}$ No entanto, o que se sabe é que a motivação dos padres era animar a vida monástica e a ordem das virgens. Por esse motivo enalteciam a prática da virgindade. A elaboração gregoriana referente à virgindade requer uma articulação entre o aspecto físico e o aspecto teológico. Essa postura é atribuída à dimensão do mistério que envolve o contexto em sua totalidade. Nessa perspectiva, se interligam dois elementos fundantes: a) é um evento extraordinário e único; b) a consideração da maternidade em sua relação com o mistério de Deus e a história salvífica. ${ }^{31}$

O termo santa excelsa, sem pecado, aplicado a Maria, adquire relevância no pensamento capadócio. Santidade nesse contexto significa consagração total a Deus e integridade corporal como ausência do pecado. Utilizou com profundidade o paralelismo antitético: Cristo-Adão, o homem novo. Resgata a argumentação de Irineu de Lião ${ }^{32}$ de que assim como Adão foi feito da terra virgem, também o novo Adão foi formado da terra virgem no seio de uma virgem. É um precioso testemunho da virginitas in partu. Aplica pela primeira vez a analogia da sarça ardente para dizer que a chama que emerge da Sarça é a figura da divindade que nasce da virgem, como a chama não destrói a sarça, assim o parto não destrói a virgindade.

Sublinha que se trata de um grande mistério, e o faz apresentando fórmulas: a) mistério da virgem; b) o mistério da virgindade; c) o mistério segundo a virgem; d) o mistério segundo a virgindade; e) o mistério que procede da virgem. A virgindade de Maria inclui o aspecto corporal, porém, não se reduz

\footnotetext{
${ }^{29}$ Essa compreensão traz à tona o termo de corpo imaculado no pensamento nisseno, onde também resgata o paralelismo de Irineu sobre Eva-Maria; Adão formado da terra virgem e o novo homem também formado da terra virgem.

${ }^{30}$ DOYLE, D., María, madre de Dios, p. 850-856.

${ }^{31}$ GREGORIO NAZIANZENO, Omelie sul Cantico dei Cantici, p. 374-378.

${ }^{32}$ MEO, S., Nueva Eva, p. 1474-1486.
} 
a esse. É um pacto nupcial com Deus de uma virgem que consagrou sua carne a Deus. $\mathrm{O}$ fato de pôr em realce a dimensão mistérica da virgindade de Maria se pode definir uma novidade absoluta referente à tradição anterior e esse é um dos aspectos mais originais de sua mariologia, sobretudo, por considerar a maternidade na sua relação com o mistério de Deus e da história da salvação.

Sua argumentação consiste em afirmar que virgindade é essencialmente pureza do ser e plenitude de perfeição. Por isso parte da virgindade existente na Trindade, ao dizer que a virgindade está no Pai como aquele que gera o Filho sem paixão; onde resplende a pureza e é fonte de incorruptibilidade; está no Espírito que possui a pureza incorruptível. Desse modo, a virgindade de Maria reflete a incorruptibilidade da natureza divina e da geração eterna do verbo, pois somente a pureza é capaz de acolher a vinda de Deus. No caso da Virgem trata-se de uma pureza imaculada. A verdadeira virgindade vem compreendida como liberdade diante do pecado, implica a santidade de total, incompatibilidade com qualquer gênero de pecado. Faz uma analogia entre Eva e Maria referente à arvore da vida e a cruz, a primeira abriu as portas ao pecado, a segunda abriu as portas à justiça. ${ }^{33}$

Gregório de Nissa é um autor voltado à perspectiva mística tendo como primazia fontal a Sagrada Escritura, orientado para a exegese e a ética. ${ }^{34}$

\section{Conclusão}

A mariologia presente nos escritos de Basílio permanece fiel à tradição anterior, sobretudo, ao pensamento mariológico de Orígenes. A mesma mantém a afirmação teológica de Orígenes: que já a denominava Theotókos. Tratase da questão mariológica articulada ao mistério de Cristo. Em sua homilia sobre o Natal percebe-se um dos aspectos mais importantes da doutrina sobre Maria na literatura das homilias gregas mais antigas. A virgem nunca aparece separada do Filho, o que afirma sobre ela é sempre para esclarecer elementos do mistério de Cristo. Na homilia sobre a encarnação descreve com certa amplitude a missão de Maria no mistério cristológico e pneumatológico e, portanto, parece que essa precisão doutrinal, veladamente polêmica, quer abrir caminho ao desenvolvimento mariológico posterior.

\footnotetext{
${ }^{33}$ MATEO-SECO, F. L., Mariologia, p. 374-378.

${ }^{34}$ MORESCHINI, C.; NORELLI, E., História da literatura cristã antiga grega e latina, II do Concílio de Nicéia ao início da Idade Média, p. 160.
} 
Referente ao pensamento de Nazianzeno, embora, o leitor moderno e pós-moderno se perceba diante de um texto elaborado de forma negativa, entende a luta para defender a divina maternidade, a unidade da pessoa de Cristo e a realidade da concepção através de uma virgem. Outro ponto em sua doutrina faz referência à purificação de Maria em vista da sua participação na encarnação. O objetivo é afirmar a encarnação do Verbo por meio de uma virgem purificada, que se torna modelo ascético.

Gregório de Nissa contribui pela primeira vez com a analogia entre o parto virginal de Cristo e a geração eterna do Verbo como argumento contra as doutrinas arianas: nascendo de Maria, Cristo não corrompe sua integridade física, assim como nascendo eternamente do Pai o verbo não induziu naquele que o engendrou nenhuma paixão ou situação de mudança. A importância disso abre caminhos para as homilias dos séculos seguintes. Na homilia de Gregório de Nissa sobre a Natividade afirma-se que, com a anunciação, floresce a alegria e desaparece a tristeza, enquanto Deus se deleita na beleza das almas.

Os capadócios deram uma grande contribuição à Tradição dogmática da Igreja sobretudo à cristologia e à teologia trinitária contra os arianos defendendo a consubstancialidade do Verbo com o Pai e contra Apolinário mostrando a importância da completa e perfeita humanidade do Verbo encarnado. Sobre esses pilares fundamentais repousa sua doutrina mariana, uma mariologia cristológica.

Os padres capadócios são hábeis em tentar responder às interrogações e a problemas pastorais de seu tempo. Há preocupação em criar uma linguagem que defina a fé na Pessoa de Jesus Cristo como Filho de Deus encarnado, e como articular a pessoa de Maria nessa dinâmica: mariologia e cristologia são inseparáveis na busca de compreensão do mistério.

\section{Referências bibliográficas}

DAMIGELLA, G. Il mistero di Maria, teologia, storia, devozione. Roma: Città Nuova, 2005.

DOYLE, D. María, madre de Dios. In: FITZGERALD, D. A. (Org.). Diccionario de San Agustín, san Agustín a través del tempo. Burgos: Monte Carmelo, 2001. p. 850-856. 
GIANOTTO, C. Maria. In: MONACI CASTAGNO, A. (Org.). Origene. Dizionario: la cultura, il pensiero, le opere. Roma: Città Nuova, 2000. p. 263-266.

GREGORIO DI NISSA. Omelie sul Cantico dei Cantici. Bologna: EDB, 1995.

GREGÓRIO NAZIANZENO, Apud GAMBERO, L. I padri cappadoci (Basilio Magno, Gregorio Nazianzeno, Gregorio Nisseno) testimoni della tradizione mariana. p. 1-10. Disponível em: $<$ http://www.culturamariana. com/pdf/08-01-2011.pdf>. Acesso em: 24 jun. 2017.

GREGÓRIO NAZIANZENO. Tutte le orazioni. Milano: Bompiani, 2000.

INÁCIO DE ANTIOQUIA. Cartas de Santo Inácio de Antioquia. Comunidades eclesiais em formação, Petrópolis: Vozes, 1970.

INÁCIO DE ANTIOQUIA. Policarpo. Martirio di Policarpo. Milano: Mimep-Docete, 1996.

KOESTER, H. Introdução ao Novo Testamento. São Paulo: Paulus, 2005. vol. 2.

PERETTO, E. Mariologia Patrística. In: QUACQUARELLI, A. (Ed.). Complementi interdisciplinari di patrologia. Roma: Cittá Nuova, 1989. p. 697- 756.

MATEO-SECO, F. L. Mariologia. In: MATEO-SECO, F. L.; MASPERO, L. (Eds.). Dizionario de Gregorio di Nissa. Roma: Città Nuova, 2007. p. 374-378.

MEO, S. Nueva Eva. In: FIORES, S.; MEO, S. (Orgs.). Nuevo Diccionario de Mariología. São Paulo: Paulinas, 1988. p. 1474-1486.

MORESCHINI, C.; NORELLI, E. História da literatura cristã antiga grega e latina, II do Concílio de Nicéia ao início da Idade Média. São Paulo: Loyola, 2000. vol. 1.

SARTOR, D. Madre de Dios. In: FIORES, S; MEO, S. (Orgs.). Nuevo Diccionario de Mariología. São Paulo: Paulinas, 1988. p. 1173-1199.

TONIOLO, E. Padres de la Iglesia. In: FIORES, S; MEO, S. (Orgs.). Nuevo diccionario de mariologia. Madrid: Paulinas, 1988. p. 1514-1553.

TONIOLO, E. Testi mariani del primo millennio: Padri e altri autori greci. Roma: Città Nuova, 2001. vol. 1. 
TRISOGLIO, F. San Gregorio di Nazianzo: un contemporâneo vissuto sedici secoli fa. Torino: Effatà, 2008.

Maria Freire da Silva Doutora em Teologia Dogmática pela Pontificia Università Gregoriana di Roma Professora do Curso de Graduação em Teologia na Pontifícia Universidade Católica de São Paulo São Paulo / SP - Brasil E-mail: mfreire.silva@pucsp.br

Recebido em: 30/06/17 Aprovado em: 14/04/18 